\title{
Extra-Curricular Activities and Teacher Attitude to Girl-Child Education and Psycho-Emotional Preparedness
}

\author{
Osiki Jonathan Ohiorenuan \\ National University of Lesotho, Department of Theology and Religious Studies, Faculty of \\ Humanities, P.O.Roma 180, Lesotho \\ E-mail: jonathanosiki@yahoo.co.uk
}

KEYWORDS Extracurricular activities; teacher; attitude; girl-child; psycho-emotional preparedness.

\begin{abstract}
The study examined how teacher attitude and variation in extracurricular programmes affect the Girl-Child emotional preparedness. The descriptive survey design following the multi-stage sampling technique was employed to pick participants from the thirty-six states and the Federal Capital City (Abuja), Nigeria for the study. Using the stratified sampling method, the simple random technique was utilized to select one thousand, seven hundred and sixteen $(1,716)$ primary school teachers with age range of between 18 and 57 years $(\mathrm{x}=39.64, \mathrm{SD}=$ 11.3). The Teachers' Perception of Pupils Attitude to Schooling Scale (TPPAS), the School Extracurricular Activities (SEA) and the Feeling Perceptual Scale (FPS) were the research instruments used in the study. The simple descriptive statistics of relative frequency counts was utilized for analysis. The findings showed among others, that the primary school teachers' perception of girls' attitude, as compared to the boy-child, in going to school was negative. It showed that $73.2 \%$ of the teachers affirmed that the girl-child is not interested in going to school while $79.9 \%$ of the pupil who are girls said that they are frightened to go to school sometimes due to their teachers' treat of beating them. Moreover, while over $90.0 \%$ of the schools had extracurricular facilities for the boy-child, the facilities for the girl-child are either not available and, or are minimally provided. The findings showed that the education of the girl-child, as compared to that of the boy-child is at variance due to their negative perception. It further showed that the attitude of teachers is not supportive to facilitate the emotional development of particularly the girl-child. The study recommended that Governmental policies should be designed to provide the girl-childfriendly school facilities that can advance the benefits of extracurricular activities for the learners.
\end{abstract}

\section{INTRODUCTION}

Prominent among the critical issues of life that is usually neglected, is the dimension on how the school child learns. With particular emphasis on the girl-child, the way she is emotionally prepared to learn academically and succeed by the school teacher especially, has suffered a lot of neglect. From the perspective of one paradigm, when all necessary stimulation (i.e. learning of tasks, tasks differential - arrangements on age-basis and the provision of experienced facilitators) are provided, the girl-child should learn well to achieve expected academic performance. Some others are of the opinion that so long as the learner goes to school and is regular, her academic performance should not be inhibited. While these paradigms may have some merits, for the child to learn and sustain the needed motivation required to achieve academically, the learner's emotion must however be stable and commensurate. The girl-child emotional preparedness or status is the total feelings that predispose her mental alertness and readiness to ensure productive learning.
The girl-child's emotional preparedness is a function of her personal relaxation and which can be maintained by the attitude of significant persons especially within the school system. Though attitude is a dynamic psychosocial construct that changes over time, it can be reinforcing while at the same time, disruptive. In consequence therefore, the child's ability to achieve and excel academically can be as predictive as the degree to which she is regarded and perceived within the community as well as their personal happiness. Her happiness and whether others are happy about her presence to compete within any given environment as the school, and concomitantly the attitude of especially the school teacher may be an important index in her emotionality. The perception of this paradigm is that it is the school teacher who arranges class tasks to facilitate learning materials as well as the facilities that may be provided for extracurricular activities needed to boost relaxation in the learners.

This analogy is hinged on the Schachter Singer theory (cited as Coon, 1995) that the way the individual emotes is underscored by a 
number of interacting factors. According to the theory which explains the basis of the present study, the triplex factors predicting emotional trends are: (a) presence of environmental stimulus; (b) sense of heightened physiological arousal and (c) cognitive appraisal of the situation (that is, a juxtaposition of the memory of similar situation from the past with the current interpretation of environmental events). In the perception of Schachter and Singer (1995) emotional distortions sets in whenever the tipple conditions are at variance.

In educational psychology, emotional distortions are perceived as a learning disability or behavioural disturbance of enough severity to render the affected learner inability to function within any regular classroom. The emotionally handicapped girl-child, although might have been a person of either average or superior intelligence and may demonstrate no gross neurological disorder, but nonetheless, is unable to learn or maintain satisfactory interpersonal relationships with peers and teachers. Additionally, the girl-child may over react to what may appear to any observer to be minimal stress and may develop any number of somatic or psychic symptoms in relation to ordinary school pressure, or she may show generalized unhappiness and disenchantment with living.

\section{A Survey of Related Studies}

Without any doubt, quite a substantial number of evidences are implicated on the complexities and interconnectedness of extracurricular activities and attitude, and on how they are annexed to determine the emotional development of the learner. While such studies as Lebanidze, Baliauri, Oganezor, Dundua and Sumenko (2000); Mialovyts'ka, Gulkevych and Lembers'ka (2000); Curran, Ponsford and Crowe (2000) provided information on the relative importance of psychoemotional outcome, their findings are however limited to the exclusion of the precipitating factors responsible for such emotional outcome. For instance, the studies of Maraffi (2005); UNICEF (2005); Arnot and Marshall (2005) as well as Casely - Hayford (2005) have elucidated on the potency of attitude in predicting the direction of emotion. Wrong perception both of objects and individuals may negatively affect the individual's mannerism and self esteem. Maintaining poor self-esteem of oneself unarguably dictate the inclination and obvious avoidance, otherwise, the reluctance for accepting to undertake a task as in learning activities.

In the academic pursuits of rural elementary students, Swetman (1995) reported that though initially, girls demonstrated more positive attitudes towards mathematics than boys, as they continued in school, girls' attitudes became more negative. Discussing the motivating factors for this, teachers' were implicated just as Schwartz and Hanson (1992), Leach (1994) and Guthezahl (2005) when in their opinions said that the school teachers' negative attitude about the girl-child and what they can do, exaggerated the low-attainment level of female pupils. By that simple analogy, the more negative the female pupils' prowess are perceived the higher their withdrawal from task - competition due to emotional stress. Such disabling condition which are reinforced among significant personnel within the school negatively affect the girl-child's propensity to explore their physical, creative social, political and career interests which are part of the dividends arising from possible participation in outside the school activities (i.e. extracurricular). The rather unfortunate situation is the gullible nature which subsequently becomes easy past time for the female pupils when they are married.

Considering the relevance of extracurricular activities and their relationship with attitude and in predicting the emotionality of participants, the findings encapsulated in Hollrah (2000) are quite outstanding. In that study, questions were generated to find out on the benefits of extracurricular activities to students when they are provided. It was also aimed at finding out some of the reasons why participants who get involved with extracurricular activities get better grades. Other questions include: whether it matters on the type of activity that the students are in and, or why does the state University of Iowa gets on the regular - funding of clubs and organizations? The final and critical question was to find out on how activities are vital component of a well-rounded education? In the findings as presented in Hollrah (2000), students involved in extra curricular activities received better grades than those not involved. Overall, activities were found to improve the students in character building lessons, life long skills, preventing the at - risk students from dropping out of school while their social skills are also well developed. 
Though Hollrah (2000) did not differentiate on gender performance, the overall implication was that better attitude invested in the Iowa State University students was a spring board for their emotional wellness which triggered and compensated in high standards both in academics as well as other aspects of life. This got support from Rombokas (1995) previous studies who in a correlational investigation involving two hundred and ninety-two college students reported that participation in extracurricular activities enhances both the intellectual and social development of students. Through participation and persevering in any of the suggested activities, Rombokas concluded that the students gained a sense of self-respect, self-esteem, and self-confidence while $74.6 \%$ of the students reported that they felt team sports are excellent way to build character.

However, profound as these studies are, the key fact is that attitude can affect how facilities are provided and used. When girl-child friendly facilities are provided and that the female pupils are positively encouraged to participate in their usage as the boy-child, she can be happy and emotionally fulfilled.

\section{Aim of the study}

The area of focus of the study was to investigate the primary school teachers' attitude to access and participation of the girl-child in education as well as to ascertain the provision and distribution of school facilities to cater for equal access of gender. The assumption is that teacher attitude to the girlchild access to and participation in education and equal opportunity in extracurricular activities would boost the emotional status needs of the girl-child to stimulate her readiness and preparation to achieve academically.

\section{The Location of Study}

The study spans through ten automation selected states of Nigeria. These comprise two southern states which are Ebonyi and Edo and eight northern states (i.e Bauchi, Borno, Jigawa, Kano, Katsina, Niger, Sokoto and Yobe) respectively. While the eight selected states are predominantly muslims with moderate Christian adherents, the two Southern states are mostly Christians with very scanty people of the Islamic faith. Interestingly, about $80 \%$ of the Selected
States are of the Peoples Democratic Party (PDP), and is the leading political party in Nigeria with very massive membership.

Nigeria is situated on the western coast of Africa, lying between latitude $4^{\circ}$ and $14^{\circ}$ north and between longitudes $3^{\circ}$ and $15^{\circ}$ east. With a surface area of 923,764 sq. km. Nigeria has its borders with Cameroon to the East, Niger and Chad to the North and Benin to the west. To the South, it has $800 \mathrm{Km}$ of Atlantic Coastline along the Gulf of Guinea. Nigeria, being the most populous country in Africa also boasts of being the largest single country in the black Diasporas. Nigeria is a multi-religious and multi-ethnic country; and has had very unstable and unprecedented history as far as her political career is concerned; but until recently, in 1999 when a stable democratically elected government came to power. Since then, she has been embattled with the problem of reconstruction politically, socio-economically and educationally.

Before now, the education sector in particular, was said to be near collapse amidst very lopsided policies and unfavourable circumstances hampering the best of programmes geared toward education for all. In a summarized statement of the president of the Federal Republic of Nigerian in 1979 and as provided in FME (2000) report, it said "in Nigeria, our administration is fully conscious of the decline to our educational standards and the decay of the whole system within the last couple of decades. The Nigerian educational system is as it stands a living proof of the damages that bad governance can do to any society and social structure" (cited in Education Sector Status Report (2003, p.15).

\section{Research Questions}

1. How do the school teachers perceive the girlchild education?

2. What is the girl-child attitude to schooling?

3. What is the nature of facilities in schools?

4. To what extent are sporting facilities provided on the basis of gender equity in schools and in boosting extracurricular activities?

5. How does the girl-child feel about going to school?

\section{METHODOLOGY}

Design: The descriptive survey research design was used in the study. The SAGENBaseline Study was conducted to identify the 
key factors affecting girls' participation and achievement in Schools as first step to the introduction of intervention programmes to schools in Nigeria. Since the study is aimed at finding out opinions and attitude of individuals in the girl-child participation in and access to education, the descriptive Survey design is considered the most appropriate.

Sample and Sampling Procedure: The multistage Sampling technique was employed to pick participants from the thirty-six states and the Federal Capital City (Abuja) for the study. The states were later stratified into two zones using the North and South polarization method. Using the thumb rule, and the study is presently a baseline project, eight states were chosen from the North while only two were taken from the South to make up ten states in all. Through a random table of selection, six local government areas each from the ten states were picked by way of automation while twelve primary schools, with the alternate facilities for Child-Friendly (i.e. UNICEF - Assisted Schools) and the nonassisted category were used. The simple random method was used to select one thousand, seven hundred and Sixteen $(1,716)$ primary school teachers for the study. The educational qualifications of the teachers are varied to include Junior/Senior Islamic Certificates (JIC/SIC), West African School Certificate(WASC); National Certificate of Education (NCE), Grade II Teachers Certificate, Ordinary /Higher National Certificate and University degrees (i.e. B.A./B.Sc. (Ed.), B.Ed., M.A, M.Sc., M.Ed., PDGE etc.) Majority of the participants were predominantly Muslims with the exception of the few from the two Southern part of Nigeria.

The age range of the School teachers was between 18 and 57 years $(\mathrm{X}=39.64, \mathrm{SD}=11.3)$. Their mean value was $48.31(\mathrm{SD}=17.2)$.

Research Instrument: The instruments utilized for the study include the Teachers' Perception of Pupils Attitude to Schooling (TPPAS) adapted from the Teachers' Questionnaire (SAGEN/01/TQ/03A); The School Extracurricular Activities(SEA) adapted from School Compound/Facility Sub-Scale in SAGEN/ 01/SOD/02A(Sub-Sections 6,7,8,9,10, and 11); as well as the Feeling Perceptual Scale(FPS) an adaptation of the Pupils Attitude to Schooling Scale.

The Teachers' Perception of Pupils Attitude to Schooling (TPPAS) was constructed to elicit response on how the teacher perceive attitude of the Girl-Child to schooling while at the same time, making a comparison to boy's attitude. The TPPAS comprises 14 items and is structured in the modified 4-Likert point Scale of "Strongly Agree" (4 points); "Agree" (3 points) "Disagree" (2 points) and "Strongly Disagree" (1 point) respectively. The maximum score obtainable in the TPPAS is 56 while the minimum score is 14 . With the use of the Cronbach Alpha, the internal consistency of the instrument had the correlation Coefficient(r) value of 0.92 .

The second adapted instrument was the "SEA". The SEA was designed as School Compound/Facilities Observation Schedule to elicit information on the provision of school facilities. The SEA contains two sub-sections of "A" and "B". The section "B" of the SEA with sub-sections $6,7,8,9,10$, and 11 were adapted. The adapted Observation Schedule was screened to ensure its strict contents for use as a baseline schedule by psychometricians.

The Pupils attitudes to schooling (PAS) was constructed to elicit the girl-child response on her attitude to schooling) and to confirm otherwise the teachers perception to schooling sub-scale. Designed in the modified 2-point Likert scale, using the Pearson product moment a correlation coefficient (r) of 0.76 was obtained.

However, it is important to indicate that while the entire SAGEN baseline study developed and constructed 18 Comprehensive major scales, some of the major scales equally had Sub-Scales with Sectional Sub-themes. The final 18 major Scales went through several weeks of design, pilot testing; cleaning and re-construction before the final application to the ten automatedSelected States for the baseline study.

Procedure for Data Collection: Prior to the data collection exercise, two separate meetings of one and two weeks and at different locations were organized for both the Consulting Institute (i.e. UNN/Institute of Education) in consultation with ESA/UNICEF and the recruited researchers to brainstorm on the meanings of key terms in the various instruments. The brainstorming sections provided current and acceptable meanings and refinement to critical terms in the developed instruments. Following these exercises, another one-week of training in the ten baseline SAGEN States was equally organised to train the data field collectors. The local data collectors had the privilege of corroborating the training section with some field 
trial-testing of instrument. The actual data collection was done for one week in six local government areas in each of the ten states simultaneously.

Data Analysis: The Simple descriptive statistics of frequency counts and percentages was the computational methods used for data treatment. The rationale for using purely the descriptive Statistics was due to the descriptive information derived from the study.

\section{FINDINGS AND DISCUSSION}

While education without doubt provides the basis for the girl-child empowerment economically, attitude easily directs how she would be educated. The table shows the summary of the findings on teachers' perception of pupils' attitude to schooling and parents' attitude to the participation in, and access of the girl-child to education.

\section{How Does the School Teacher Perceive the Girl-Child Education?}

The school teacher occupies a very important position in the education of the child while in particular, the education of the girl-child. Apart from dispensing knowledge, the teacher keeps different school records as the class and subject attendance registers to facilitate adequate teaching-learning in the school. Since the teacher keeps different school records, he is in the most vantage position to bring about the expected change in the girl-child participation in and access to education. To find out therefore on how the teachers perceive the girl-child education, the information as summarized in table 1 then becomes necessary.

As gleaned from the summarized table 1, the findings overall showed that teachers' perception of girls' attitude, as compared to the boy-child, in going to school was negative. Each of the alternate item-statements that elicited the teachers' perception easily betrays their opinions on the girl-child school-going behaviour. The pooled responses in item I of the TPPAS (i.e. using the percentage scores of "SA" and "A") was $73.2 \%$ affirming that the girl-child is not interested in going to school.

In the alternate item-statement as depicted in item number 2 , table 1 , the pooled responses of the teachers showed that $87.0 \%$ of them said that the boys are interested at going to school where only $26.8 \%$ favoured the girls (see item number 1 , using the "D" and "SD" summaries) respectively. This findings were equally supported when the pooled item responses of number 5, where the 'D' and "SD" summaries are utilized. From the tabular details, $73.1 \%$ of the respondents opined that evidence abound to support the notion that girls dislike schooling whereas only $13.7 \%$ was accounted for the boy-child.

While other details are briefly summarized in the table, the teachers' perception of the girlchild schooling behaviour can have some grave consequences on especially her psychology. When obvious discrepancies like this exists, and in particular, comparing the girl-child to the boy, the girl-child gets deflated so easily in her selfesteem and may momentarily resign her life's prospect to fate. Such a mannerism may also affect her potential to succeed academically and in other related tasks.

\section{What is the Girl-Child Attitude to Schooling?}

The information in table I above would be more meaningful if a juxtaposition of the girl-child attitude to schooling as perceived by her is ascertained (otherwise, verified). The summarized details of the findings are depicted in table 2 .

The information indicated in the above table 2 were got from 1058 female pupils. Very critical item-statements shown in this table are in item numbers 1, 10, 13, 14 and 15 as well as item 11 . Specifically administering the scale to randomly selected female pupil respondents, the findings in the identified item-statement/responses showed that the girl-child" perception of schooling was positive. For instance $90.0 \%$ of the female respondents as against $10.0 \%$ posited that they like going to school. However, as inferred from item-statement ' 4 ' only $29.0 \%$ of the female respondents indicated that they are not happy whenever, for any apparent reason if they failed to go to school. Unfortunately though, $71.0 \%$ of these girls gave a negative response to indicate that, perhaps, they are not bothered; and this may be lending support, and very strongly to the opinion of the school teachers that the girl-child is not interested at going to school (see item 1, in the TPPAS instrument). Although additional finding as indicated in item 10 , showed that $85.9 \%$ of the girls submitted that school work is important to them, their earlier 
Table 1: Teachers' perception of pupil's attitude to schooling

\begin{tabular}{|c|c|c|c|c|c|}
\hline S.No. & Attitude Statements & $S A$ & $A$ & $D$ & $S D$ \\
\hline 1. & $\begin{array}{l}\text { Girls in this school do not have much } \\
\text { interest in schooling }\end{array}$ & $643(42 / 6 \%)$ & $461(30.6 \%)$ & $2298(19.7 \%)$ & $107(7.1 \%)$ \\
\hline 2. & $\begin{array}{l}\text { Boys in this school do not have much } \\
\text { interest in schooling }\end{array}$ & $111(7.0 \%)$ & $96(6.1 \%)$ & $581(36.7 \%)$ & $796(50.3 \%)$ \\
\hline 3. & Girls come to school as much as possible & $248(14.6 \%)$ & $298(17.5 \%)$ & $709(411.7 \%)$ & $447(26.3 \%)$ \\
\hline 4. & Boys come to school as much as possible & $651(37.2 \%)$ & $784(44.8 \%)$ & $103(5.9 \%)$ & $211(12.1 \%)$ \\
\hline 5. & $\begin{array}{l}\text { There is no indication that girls in this } \\
\text { school dislike schooling }\end{array}$ & $208(12.4 \%)$ & $241(14.4 \%)$ & $843(50.4 \%)$ & $380(22.7 \%)$ \\
\hline 6. & $\begin{array}{l}\text { There is no indication that boys in this } \\
\text { school dislike schooling }\end{array}$ & $541(40.7 \%)$ & $605(45.6 \%)$ & $78(5.9 \%)$ & $104(7.8 \%)$ \\
\hline 7. & $\begin{array}{l}\text { On market days, girls' attendance to } \\
\text { school is usually very poor }\end{array}$ & $601(37.1 \%)$ & $589(36.4 \%)$ & $288(17.8 \%)$ & $142(8.8 \%)$ \\
\hline 8. & $\begin{array}{l}\text { On market days, boys' attendance to } \\
\text { school is usually very poor }\end{array}$ & $480(37.0 \%)$ & $591(45.5 \%)$ & $130(10.0 \%)$ & $98(7.5 \%)$ \\
\hline 9. & $\begin{array}{l}\text { Girls in this school do not see schooling } \\
\text { as a serious business }\end{array}$ & $599(41.0 \%)$ & $481(32.9 \%)$ & $201(13.7 \%)$ & $181(12.4 \%)$ \\
\hline 10. & $\begin{array}{l}\text { Boys in this school do not see schooling } \\
\text { as a serious business }\end{array}$ & $413(31.4 \%)$ & $78(5.9 \%)$ & $291(22.1 \%)$ & $534(40.6 \%)$ \\
\hline 11. & $\begin{array}{l}\text { Girls are motivated to come to school } \\
\text { whenever school is open }\end{array}$ & $398(29.1 \%)$ & $491(35.9 \%)$ & $204(14.9 \%)$ & $276(20.2 \%)$ \\
\hline 12. & $\begin{array}{l}\text { Boys are motivated to come to school } \\
\text { whenever school is open }\end{array}$ & $543(35.7 \%)$ & $623(40.9 \%)$ & $156(10.2 \%)$ & $200(13.1 \%)$ \\
\hline 13. & $\begin{array}{l}\text { During farming season fewer boys come } \\
\text { to school }\end{array}$ & $397(33.8 \%)$ & $465(39.6 \%)$ & $99(8.4 \%)$ & $213(18.1 \%)$ \\
\hline 14. & $\begin{array}{l}\text { During farming season fewer girls come } \\
\text { to school }\end{array}$ & $430(30.0 \%)$ & $275(19.2 \%$ & $517(36.1 \%)$ & $209(14.6 \%)$ \\
\hline
\end{tabular}

Table 2: Pupils' attitudes to schooling

\begin{tabular}{|c|c|c|}
\hline S.No.Item-Statements & Yes & No \\
\hline I do not like to be absent from school any day. & $757(90.0 \%)$ & $84(10.0 \%)$ \\
\hline It does not matter if I am absent from school, I can copy the notes. & $358(54.3 \%)$ & $3011(45.7 \%)$ \\
\hline I don't have much interest in going to school. & $566(53.6 \%)$ & $489(46.4 \%)$ \\
\hline I do not feel happy any day I fail to go to school. & $275(29.0 \%)$ & $674(71.0 \%)$ \\
\hline I hate going late to school any day. & $455(41.9 \%)$ & $631(58.1 \%)$ \\
\hline I often can't do my homework because I have jobs to do at home. & $673(61.4 \%)$ & $423(38.6 \%)$ \\
\hline I avoid going to school sometimes because I do not like our teacher. & $585(55.3 \%)$ & $472(44.7 \%)$ \\
\hline Sometimes I am frightened of going to school because the bigger pupils beat me. & $301(54.0 \%)$ & $256(46 . \%)$ \\
\hline Sometimes I am frightened of going to school because my teacher beats me & $799(79.9 \%)$ & $201(20.1 \%)$ \\
\hline 10. School work is very important to me. & $812(85.9 \%)$ & $133(14.1 \%)$ \\
\hline 11. I like to go to school always, even if it is on market days. & $514(54.6 \%)$ & $428(45.4 \%)$ \\
\hline 12. Any day our teacher plans to give us test, I stay back at home. & $308(39.1 \%)$ & $479(60.9 \%)$ \\
\hline Most of the things we learn at school are useful to me. & $652(73.2 \%)$ & $239(26.8 \%)$ \\
\hline 14. Whatever we learn at school is important for me. & $756(66.5 \%)$ & $380(33.5 \%)$ \\
\hline 15. I enjoy school activities which our teacher plans for us. & $681(59.8 \%)$ & $457(40.2 \%)$ \\
\hline 16. I go to the market on market days, even it is also a school day. & $348(43.6 \%)$ & $450(56.4 \%)$ \\
\hline
\end{tabular}

response to item 4 above, easily betrays their overall feelings as regard school-going behaviour. This was further supported when $79.9 \%$ of the girls said that sometimes they may not also go to school whenever the teacher threatens; as shown in table 2, item ' 9 '.

\section{What is the Nature of Facilities Available in Schools?}

The school facilities so referred to here are different category of playgrounds provided within the school (i.e. their status), play items (e.g. climbers, swings, merry-go-round, ball,etc) and which also included sporting facilities needed for extracurricular activities One important feature of the section is to identify on how some of the facilities are provided on gender equity. The table 3 following the discussion vividly summarized the findings.

As indicated in table 3 , out of 120 primary schools investigated in the ten SAGEN-Baseline 
study states, 11(9.2\%) of the schools had 3 and above, while $8(6.7 \%)$ had only 2 playgrounds respectively. The findings further showed that while $17(14.2 \%)$ of the schools had no playground, $86(71.7 \%)$ however had one each. The implication, particularly for those schools without playgrounds is that the added advantage of skill-acquisition which individuals learn from the perspective of being part of a team would have been lost. The table 4 is a summary of the status of the playgrounds in schools.

Table 3: Number of playground(s)

\begin{tabular}{llcc}
\hline S. No. Items & Number & Percentage \\
\hline 1 & 3 and above playground & 11 & 9.2 \\
2 & 2 & 8 & 6.7 \\
3 & 1 & 86 & 71.7 \\
4 & None & 17 & 14.2 \\
\hline
\end{tabular}

From the table 4, 51(42.5\%) out of a total of 120 primary schools used for the study had bare playgrounds (i.e. ungrassed) while $48(40.0 \%$ ) had partly-grassed playgrounds. Twenty-one of the schools however only had their playgrounds completely grassed. The playgrounds with completely grassed condition are better desired for curtailing the possibility of likely hazards particularly for primary school children. The information on the status of the playgrounds with complete grassed coverage is provided in table 5 .

Table 4: Condition of playground(s)

\begin{tabular}{|c|c|c|c|}
\hline S. No & Items - statement & Number & Percentage \\
\hline 1 & Completely grassed & 21 & 17.5 \\
\hline 2 & Partly grassed & 48 & 40.0 \\
\hline 3 & Bare (ungrassed) & 51 & 42.5 \\
\hline
\end{tabular}

Table 5: If grassed indicate status

\begin{tabular}{|c|c|c|c|}
\hline S. No & Items - statement & Number & Percentage \\
\hline 1 & Bushy & 7 & 33.3 \\
\hline 2 & Mowed regularly & 14 & 66.7 \\
\hline
\end{tabular}

As shown in table 5, out of the 21 playgrounds that are completely grassed, $7(33.3 \%)$ are rarely maintained and bushy while $14(66.7 \%)$ are however mowed regularly. Having playgrounds that are completely grassed and are not maintained can pose dangers particularly for children of primary school age.

The summary table 6 showed that among the 51 schools with bare playgrounds, $17(33.3 \%)$ of the schools had completely sandy layout while $8(15.7 \%)$ were stony; and $2(3.9 \%)$ others had a muddy background. However, 5(9.8\%) had undulating playgrounds although $19(37.3 \%)$ others had playgrounds that are flat.

Table 6: If bare (ungrassed) indicate status

\begin{tabular}{|c|c|c|c|}
\hline & No. Items - statement & Number & Percentage \\
\hline 1 & Sandy & 17 & 33.3 \\
\hline 2 & Stony & 8 & 15.7 \\
\hline 3 & Muddy & 2 & 3.9 \\
\hline 4 & Undulating & 5 & 9.8 \\
\hline 5 & Flat & 19 & 37.3 \\
\hline
\end{tabular}

In table 7 , the playground facilities available in the 120 primary schools are summarized. The climbers and the swings were not found in any of the study school location. However prominent among the findings is that the football is common feature in most of the schools. The talking drums were ranked second in the other of availability in the schools.

Table 7: Playground facilities (specify any)

\begin{tabular}{llcc}
\hline S. No. & Items & Number & Ranking \\
\hline 1 & Climbers & - & - \\
2 & Swings & - & - \\
3 & Merry-go-round & 2 & 6 \\
4 & Tyres & 5 & 4 \\
5 & Ropes & 11 & 3 \\
6 & Balls & 95 & 1 \\
7 & Slides & 3 & 5 \\
8 & Drums & 36 & 2 \\
\hline
\end{tabular}

\section{To What Extent are Sporting Facilities Provided on the Basis of Gender Equity in Schools and in Boosting Extracurricular Activities?}

Provision of sporting facilities and the participation of school pupils can be very benefiting as a veritable source for curricular activities. It can be the basis for characterbuilding lessons and lifelong skills in children. Additionally, the problem of school dropout may be curtailed while pupils can acquire needed skills for social development, gain sense of selfrespect, self-esteem, and self-confidence. In table 8 below, the summary of the findings are presented.

The information gleaned from table 8 showed that majority of the schools have facilities for the football field while in such games as volleyball pitch, Hockey pitch, and Badminton court, none 
Table 8: Sporting facilities for extracurricular

\begin{tabular}{|c|c|c|c|c|c|c|}
\hline \multirow{2}{*}{$\begin{array}{l}\text { S. Facility } \\
\text { No. }\end{array}$} & \multicolumn{3}{|c|}{ Condition of facilities } & \multirow{2}{*}{ 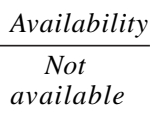 } & \multicolumn{2}{|c|}{ Utilization } \\
\hline & $\begin{array}{l}\text { Number } \\
\text { good }\end{array}$ & $\begin{array}{l}\text { Number Fairly } \\
\text { good }\end{array}$ & $\begin{array}{l}\text { Number } \\
\text { bad }\end{array}$ & & Used by girls & Used by boys \\
\hline 1. Football field & 92 & 23 & 3 & 2 & $2(1.7 \%)$ & $118(98.3 \%$ \\
\hline 2. Basketball pitch & 41 & 5 & - & 74 & - & $46(100.0 \%$ \\
\hline 3. Volleyball pitch & - & - & - & - & - & \\
\hline 4. Lawn Tennis court & 6 & 6 & - & 114 & - & $6(100.0 \%)$ \\
\hline 5. Table Tennis court & 12 & 12 & - & 108 & - & $12(100.0 \%)$ \\
\hline 6. Hockey pitch & - & - & - & - & - & \\
\hline 7. Badminton court & - & - & - & - & - & \\
\hline 8. Race track & 16 & 16 & - & 104 & $3(18.8 \%$ & $13(81.3 \%)$ \\
\hline 9. Indoor games & 25 & 25 & - & 95 & $8(32.0 \%)$ & $17(68.0 \%)$ \\
\hline
\end{tabular}

Table 9: Girl-child feeling scale

\begin{tabular}{lrr}
\hline S. Item-statement & Yes & No \\
No. & $301(54.0 \%)$ & $256(46.0 \%)$ \\
\hline $\begin{array}{l}\text { 1. Sometimes I am frightened of going to school because the bigger } \\
\text { pupils beat me. }\end{array}$ & $799(79.9 \%)$ & $201(20.1 \%)$ \\
2. Sometimes I am frightened of going to school because my teacher & $308(39.1 \%)$ & $479(60.9 \%)$ \\
beats one & $625(73.2 \%)$ & $239(26.8 \%)$ \\
3. Any day our teacher plans to give us test, I stay back at home & $348(430.6 \%)$ & $450(56.4 \%)$ \\
4. Most of the things we learn at school are useful to me. & $566(53.6 \%)$ & $489(46.4 \%)$ \\
5. I go to the market on market days even if it is also a school day. & $275(29.0 \%)$ & $674(71.0 \%)$ \\
6. I don't have much interest in going to school & $585(55.3 \%)$ & $472(44.7 \%)$ \\
7. I do not feel happy any day I fail to go to school & & \\
8. I avoid going to school sometimes &
\end{tabular}

of the schools used for the baseline study had facilities for them. In considering the utilization of the facilities however, while the findings showed that $118(98.3 \%)$ of the schools indicated that boys prominently use the facilities only $2(1.7 \%)$ showed evidence for the girl-child utilization. The findings were equally similar with the indoor games where only $8(32.0 \%)$ of the schools said that females as against $17(68.0 \%)$ schools who indicated for boys, used the facilities. By implication, the provision and utilization of extracurricular activities in schools is so profoundly lopsided to favour especially the boy-child as against the girl-child. The none-provision of facilities in terms of equal access and participation in such extracurricular activities particularly by the girl-child can affect without doubt their perception both of self and others within the school system. For instance, the girl-child can begin to feel that they are leaving in the world of boys and, or men only and who hardly perceive them as human beings and may not be welcome to compete with them. Such a phenomenon as this may directly also affect their emotional wellbeing as well as on how, perhaps, they are stimulated and prepared to learn school tasks to achieve meaningfully

\section{How Does the Girl-Child Feel about Her Going to School?}

The way the girl-child feels about her going to school is an important index in assessing how she is prompted to learn. The way she perceive things and particularly significant persons like the teacher, within the school can predict how much time she devotes to learning as well as her persistence to succeed when she goes to school. The information on the table 9 summarizes the girl-child feelings (i.e. emotions) about the teacher in particular.

As shown in table above, $79.9 \%$ of the female pupils said that they stayed away from school due to the teacher threat as against only 20.1(item 2) who dare to; and $71.0 \%$ others are happy to stay away from school for reasons personal to them (see item 7) even though the pupils said that what they learn in the school are relevant to them (item 4) respectively. Further findings as reflected in the item-statement numbers 6 and 7 though also indicated some negative feelings, what the trend portray is that, perhaps, and for too long also, the emotion of the girl-child has been battered. Living with battered emotions and distorted thoughts can however be counter- 
productive especially in academic pursuits. Perhaps, this may be one of the reasons in the explanation for the female-child acceptance of the proposal for their early marriage which seems to compensate for the emotional stress they are subjected to by significant persons within the community. Additionally, since the individual emotional state affects the way he/she is motivated in the choices he or she makes, when emotionally stressed the motivation that the girl-child needs to achieve and sustain success may be lacking.

\section{CONCLUSION}

Outstanding facts from the findings as reflected in the tabular summaries is that, while the teachers' attitude to the girl-child is copiously on the negative, the provision and the access of use and the participation in school facilities are also at the girl-child disadvantage. This was also notably implicated on how the girl-child perceive the world of the boy-child (otherwise, the male World). Denying the girl-child equal access in school facilities also indirectly predict their degree of involvement in extracurricular activities. Such denial and negative attitude from particularly the school teacher often affect their emotional status and hence, their non-use of facilities and school reluctance behaviour.

However, in curtailing some of the likely consequences of the continuous inequality of access in and participation of the girl-child in education and extracurricular activities, the teacher may be alerted on the use of teasing and negative statements on the girl-child in particular. Both boys and girls should be equally treated, regarded and given feedback without indignity. The challenges following the participation in extracurricular activities and its relevance in boosting academic achievement for both sexes should be the responsibility of the teacher to provide while positive steps are taken to enforce equal-gender use of role models to facilitate learning in the classroom.

\section{REFERENCES}

Arnot, M. and H. Marshall. 2005. "Competing curriculum agendas for gender justice: the implications of the national, global citizenship education and EFA for the school curriculum." Paper Presented at the $8^{\text {th }}$ International Conference in Education and Development, United Kingdom; 13-15 September. Cabarkapa, M., Markovic, N. and L. Popovic. 2000.
"The psychological profile using the Minnesota mulitphasic personality inventory and the value of this test in the evaluation of post-traumatic stress disorder in combat participants." Available at: http:/ /www.ncbi.nlm.nih. gov/entrez/query.fegi? Retrieved 24/9/2005

Casely - Hayford, L. 2005. "How the poor get poorer: gendered experiences in teaching in rural deprived areas of Ghana". Paper presented at the 8th UKFIET International Conference on Education and Development, United Kingdom; 13-15 September.

Coon, D. 1995. Introduction to Psychology, 7th edition. New York; West publishing Company.

Curran, C.A., J. L. Ponsford and S. Crowe. 2000. "Coping strategies and emotional outcome following traumatic brain injury: a comparison with orthopedic patients." (On-line): http:// www.ncbi.nlm.nih.gov/entrez/query.fegi? Retrieved: 22/9/2005

Education Sector Status Report 2003. Federal Ministry of Education, Abuja, Nigeria (May), 2003.

Federal Ministry of Education (FME). 2000. Comprehensive Education Analysis Project. Secondary Data Report, Abuja:FGN/UNICEF/ UNESCO/UNDP.

Federal Republic of Nigeria (FRN). 1979. Constitution of the Federal Republic of Nigeria. Lagos: Federal Government Press.

Guthezahl, J. 2005. "How negative expectancies and attitudes undermine females' mathematics confidence and performance: A review of the literature", in M. Maraffi (ed.), Girls' Attitude, Self Expectations and Performance in Math: An Annotate Bibliography (on-line): htt://www.mathforum.org/ sarah discussion retrieved 19/7/2005.

Hollrah, R. 2000. "Extracurricular Activities." Online: http://www.iastate.edu/rhetorical105H17/hollrah/ cof.html. Retrieved 22/9/2005

Leach, L. 1994. "Sexism in the classroom: A self-one for teachers." Science Scope, 17(6): 54-59.

Lebanidze, N.G., N. C. Baliauri, A. S. Oganezov; N. G. Dundua and O. V. Sumenko. 2000. "Change in the psycho emotion status during different stages of the treatment of patients with injuries." (on-line): http://www.ncbi.nlm.gov/entrez/query.fegi. Retrieved 22/9/2005.

Maraffi, M. 2005. "Girls' attitude, self-expectations and performance in mathematics; An annotated bibliography."(On-line): http://www.mathforum.org/ -sarah/discussion. Retrieved 19/7/2005.

Mialovyts'ka, O.A., O. A. Gulkevych and O. P. Lembers'ka. 2000. "The characteristics of the psychoemotional disorders in multiple sclerosis patients studied by using the method of the mulitphasic personality inventory. (On-line)." http://www.ncbi. nlm.nig.gov/entrez/query.fcgi? Retrieved 22/9/2005.

Rombokas, M. 1995. "High school extra-curricular activities and college grades." Paper Presented at the Southeastern Conference of Counselling Personnel, Jekyll island, GA. Eric document ED391134.

Schachter, S. and J. Singer. 1995. "Cognitive, Social and Physiological Determinants of Emotional States", in D. Coon (ed), Introduction to Psychology, 7th Edition. New York: West Publishing Company. 
Schwartz, W. and K. Hanson. 1992. Equal Mathematics Education for Female Students. Newton, MA Center for Equity and Cultural Diversity

Sluetman, D. 1995. "Rural elementary students' attitude toward mathematics." Rural Educator, 16(3): 20-22.

UNICEF. 2005. "Accelerating progress in girls' education." (on line). Available at http://www. unicef.org/teachers/ girls-ed/accelerating.htm. Retrieved 19/7/2005. 